\title{
84 顎骨の放射線障害と歯牙
}

$\begin{array}{lrl}\text { 森吉 } & \text { 泰 孝・(九州大学歯学部第 } 2 \text { 口腔外科) } \\ \text { 山下 } & \text { 茂 - 由代 英 雄 (第 } 1 \text { 口腔外科) } \\ \text { 神宮 } & \text { 賢一 } \\ \text { (医学部 放射線科) }\end{array}$

口腔癌患者の放射線治療に際し、従来より照射 野に含まれる歯牙の取り扱いについては種々論議 があるが、教室では腫瘍刺敫蒾や高度罹患蒾に限 って抜歯を行い経過をみてをた。昭和 41 年から 5 年間に九大口腔外科佂入院し、放射線治療を受 けた患者の中で、6 カ月以上の観察を行っている 46 症例飞つんて、顎骨の放射障害之歯牙の関係 を中心臨床経過およびX線所見にて検討を加え たので、その結果とそれに基づいて行っている歯 冠削除法について報告した。

顎骨の放射線障害 (以下骨障害とする) は、4 6 例中 13 例（ $28.3 \% ）$ 飞発生しており、大部分 が下顎骨に認められた。有歯顎は 41 例中 12 例 ( $29.3 \%)$ 、無歯顎では 5 例中 1 例( $20 \%$ ) であった。放射線の照射様式別敒骨障害発生率を みると外部照射は 18 例中 6 例 ( $33.3 \%$ )、組 織内照射では 24 例中 4 例( $16.7 \%$ )、又外部 照射と組織内照射の併用では 4 例中 3 例 ( $75 \%$ ) であった。外部照射 18 例飞ついて線量と骨障害 との関係をみると骨障害発生群の方几高い線量の 症例が多くみられた。又骨障害発生例の最低線量 は4800 rad であった。組織内照射に関しては 今回線量と骨障害の間の関係は明らかにできなか った。

骨障害の誘因をみると歯性のものと考えられた
すのが 14 例中 6 例 $(42.9 \%)$ 、非歯性の誘因 が 5 例( $35.9 \%$ )、不明が 3 例 ( $21.4 \%$ ) で あった。歯性誘因の中で壮照射前抜歯が 10 例中 1 例 $(10 \%)$ 、照射後抜歯が 19 例中 4 例 ( $21.1 \%)$ の骨障害発生率であり、歯性感染は 1 例のみであった。骨障害発生率の高かった照射 後抜歯例の骨植之骨障害発生率をみると、骨植良 好群壮 8 例中 3 例 ( $37.5 \%$ ) と高く、骨植不良 群では 11 例中 1 例 $(9.1 \%)$ と低加っ。

以上より骨障害発生に歯牙の処置が大をく関係 しているととがわかった。中でも照射後の骨植良 好歯の抜歯が危険であると考えられた。この結果 て基づんて最近は腫痬および腫瘍治瘾部を刺激し て障害となっている骨植良好歯㤢歯せずに歯冠 削除を行っている。この歯冠削除法だと(1)歯を保 存でさる。(2)照射後の危険な抜歯を避けるととが でをるといら利点がある。

\section{コメント （阪大放 重松）}

1. 照射後の下顎骨障害の発生時期は、期限を 限定しらるものでなく、3〜 5 年をへても常て注

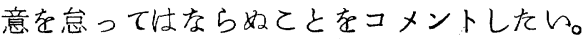

2. 演者の線量表示に、時間的因子が脱落して らる。ぜひ、時間因子を加えた線量表示として汪 しん。(TDFとか $\bigcirc \mathrm{rad} / \bigcirc \mathrm{W}$ とか)。
解答
(九大・歯・2 口外 森吉)

(1) 小線源の際にスペーサを入れるなどの工夫を してますか?

（答）今回は行っておりません。

(2) 1 門照射と 2 門照射の場合で骨障害が違らか？

（答）今回は検討しておりません。

(3) 照射後どのくらい経つと抜歯が安全だと考え てますか?

（答）どの位経つと安全であるか、はっきりと は言えをせんが、我々の経験では照射後 1 年は抜歯しない方が良いと考えます。 